\title{
PENGEMBANGAN PEMIKIRAN PENDIDIKAN ISLAM DENGAN PENDEKATAN TAFSIR TEMATIK
}

\author{
Bukhari Umar \\ Program Studi Pendidikan Agama Islam, Jurusan Tarbiyah STAIN Batusangkar \\ Korespondensi: Perum Permata Rizano, Blok b No. 9 Cubadak Batusangkar Sumatera Barat \\ E-mail: Buchariumar59@yahoo.co.id
}

\begin{abstract}
Education is buman's problem. Human is a dynamic creature. The dynamics of buman's life demands dynamic educational process in order to fulfill buman's needs. In order to maintain the dynamic thoughts of Islamic education, some relevant studies are needed. Revelation based Islamic education studies can develop the concept of Islamic education and avoid the possible mistakes made by researchers in education fields. In doing so, the researchers may use tafsir thematic approach. This is made possible since al-Quran contains much information concerning with education and guides and leads any activities of man's thoughts into those which are suitable of Islamic teaching as well.
\end{abstract}

Kata kunci: pengembangan pemikiran, pendidikan islam, tafsir tematik

\section{PENDAHULUAN}

$\mathrm{P}$ endidikan Islam merupakan proses pengembangan semua potensi peserta didik menuju terbentuknya manusia paripurna sesuai dengan ajaran Islam. Proses ini dapat berlangsung di berbagai tempat, lembaga dan dalam berbagai situasi. Di mana pun, dalam bentuk apa pun dan dalam situasi yang bagaimana pun pendidikan Islam berlangsung, ia harus diarahkan kepada pencapaian manusia ideal sesuai dengan ketentuan ajaran Islam.

Untuk mencapai tujuan yang ideal itu, pendidikan Islam harus dilaksanakan berdasarkan pemikiran yang matang. Sekecil dan sesederhana apa pun aktivitas kependidikan yang dilakukan oleh setiap muslim harus berdasarkan pemikiran yang benar. Hal ini diperlukan untuk mendapatkan hasil yang optimal dan mengantisipasi kegagalan. Bila terjadi kesalahan yang fatal, peserta didik akan mengalami kerugian besar dalam hidupnya.

Pemikiran pendidikan Islam itu harus dinamis. Ia harus mampu memberikan landasan pengetahuan pedagogik yang dapat dijadikan acuan untuk melaksanakan pendidikan dalam setiap waktu dan berbagai situasi. Bila pemikiran pendidikan Islam itu statis, maka hasilnya juga akan ketinggalan zaman dan tidak dapat mengangkat harkat dan martabat manusia muslim. Bersamaan dengan itu, pemikiran pendidikan Islam harus memiliki nilai kebenaran yang handal agar dalam perkembangan dan aplikasinya tidak melanggar normanorma ajaran Islam.

Sehubungan dengan pokok-pokok pemikiran di atas, tulisan ini mencoba mengemukakan hal-hal yang berhubungan dengan upaya pengembangan pemikiran pendidikan Islam dengan menggunakan pendekatan tafsir tematik. 


\section{PEMIKIRAN PENDIDIKAN ISLAM}

Pemikiran berarti proses, cara atau perbuatan memikir yaitu menggunakan akal budi untuk memutuskan suatu persoalan dengan mempertimbangkan segala sesuatu secara bijaksana. Dalam konteks ini, pemikiran dapat diartikan sebagai upaya cerdas (ijtihâdiy) dari proses kerja akal dan kalbu untuk melihat fenomena dan berusaha mencari penyelesaiannya secara bijaksana. Pendidikan, secara umum berarti suatu proses perubahan sikap dan tingkah laku seseorang atau sekelompok orang (peserta didik) dalam usaha mendewasakan manusia (peserta didik), melalui upaya pengajaran dan latihan, serta proses perbuatan dan cara-cara mendidik.

Konsep pendidikan Islam didasarkan kepada suatu acuan bahwa Islam sebagai agama dan system. Pendidikan menurut Islam merupakan upaya mendidikkan agama Islam atau ajaran Islam dan nilai-nilainya, agar menjadi way of lifè (pandangan dan sikap hidup seseorang). Oleh karena itu, pendidikan Islam dapat berwujud segenap kegiatan yang dilakukan seseorang atau suatu lembaga untuk membantu seseorang atau sekelompok peserta didik dalam menanamkan dan/atau menumbuhkembangkan ajaran Islam dan nilai-nilainya (Idris, 2005: 148).

Dengan demikian, yang dimaksud dengan pemikiran pendidikan Islam adalah proses kerja akal dan kalbu yang dilakukan secara bersungguh-sungguh dalam melihat berbagai persoalan yang ada dalam pendidikan Islam dan berupaya untuk membangun sebuah peradaban pendidikan yang mampu menjadi wahana bagi pembinaan dan pengembangan peserta didik secara paripurna.

Secara khusus, pemikiran pendidikan Islam memiliki tujuan di antaranya adalah: (1) untuk membangun kebiasaan berpikir ilmiah, dinamis dan kritis terhadap persoalan-persoalan di se- putar pendidikan Islam, (2) untuk memberikan dasar berpikir inklusif terhadap ajaran Islam dan akomodatif terhadap perkembangan ilmu pengetahuan yang dikembangkan oleh intelektual di luar Islam, (3) untuk menumbuhkan semangat berijtihad, sebagaimana yang ditunjukkan oleh Rasulullah dan para kaum intelektual muslim pada abad pertama sampai abad pertengahan, terutama dalam merekonstruksi sistem pendidikan Islam yang lebih baik, dan (4) untuk memberikan kontribusi pemikiran bagi pengembangan sistem pendidikan nasional.

Menurut Ramayulis, pemikiran pendidikan Islam disusun berdasarkan dua model, yaitu: (1) model idealistik dan (2) model pragmatis. Model idealistik adalah model yang lebih mengutamakan penggalian dari ajaran dasar Islam (Quran dan Hadis) dan dari hasil ijtihad/interpretasi para ulama (pakar pendidikan Islam) terutama ulama klasik. Sedang model pragmatis adalah model yang mengutamakan aspek praktis dan kegunaan. Model Pragmatis ini dilakukan dengan cara: (1) adopsi, yaitu mengambil secara utuh teori pendidikan non-Islam dan dijadikan sebagai teori pendidikan Islam, (2) asimilasi, yaitu mengambil teori kependidikan non-Islam dengan menyesuaikannya di sana sini, dan (3) legitimasi, yaitu mengambil teori pendidikan non-Islam kemudian dicarikan nash untuk jastifikasinya. Model idealistik lebih didasarkan atas kerangka dasar yang diyakini kebenarannya sehingga ia bercorak se-Islam mungkin, dibandingkan dengan model praktis (Umar, 2009: 11).

Pendapat lain dikemukakan oleh Arifin. Menurutnya, Ada dua pendekatan dalam mempelajari pemikiran pendidikan Islam, yaitu: pendekatan terhadap wahyu dan pendekatan sejarah (Jalaluddin, 1994: 28). Pendekatan wahyu adalah cara-cara yang ditempuh dalam upaya memahami kebenaran de- 
ngan menggunakan ayat-ayat Allah sebagai premis. Kebenaran dicari dengan merenungkan, menggali, menafsirkan, memperbandingkan, menghubungkan serta mentakwilkan informasi yang terkandung dalam wahyu. Dari kajian ini kemudian disusun konsep pemikiran dasar tentang pendidikan Islam.

Untuk mengembangkan pemikiran pendidikan Islam dengan pendekatan wahyu diperlukan suatu metodologi penelitian yang disebut dengan metode penelitian tafsir tematik (al-tafsîr almawdhû'iy). Sehubungan dengan itu, dalam bagian mendatang ini akan dikemukakan sekilas tentang metode dimaksud.

\section{PENDEKATAN TAFSIR TEMATIK}

Tafsir tematik (al-tafsîr al-mawdhô'iy) adalah kegiatan menghimpun ayat-ayat Alquran yang mempunyai maksud yang sama dalam arti samasama membicarakan satu topik masalah dan menyusunnya berdasarkan kronologi serta sebab turun ayat-ayat tersebut, kemudian penafsir mulai memberikan keterangan dan penjelasan serta mengambil kesimpulan. Secara khusus, penafsir melakukan studi tafsirnya ini dengan metode tematik, di mana ia meneliti ayat-ayat tersebut dari seluruh seginya, dan melakukan analisis berdasarkan ilmu yang benar, yang digunakan oleh pembahas untuk menjelaskan pokok permasalahan, sehingga ia dapat memahami permasalahan tersebut dengan mudah dan betul-betul menguasainya, sehingga memungkinkan baginya untuk memahami maksud yang terdalam dan dapat menolak segala kritik (AlFarmawi, 1994: 36-37).

Selain pengertian dan bentuk di atas terdapat pula bentuk lain tafsir tematik (al-tafsîr al-mawdhû'iy) ini. Yaitu pembahasan mengenai satu surat secara menyeluruh dan utuh dengan menjelaskan maksudnya yang bersifat umum dan khusus, menjelaskan korelasi antara berbagai masalah yang dikandungnya, sehingga surat itu tampak dalam bentuknya yang betul-betul utuh dan cermat (Al-Farmawi, 1994: 35).

Alquran penuh dengan masalahmasalah yang perlu dikaji secara tematik. Seandainya orang-orang terpelajar sudi mengabdikan diri dan mau memperhatikan masalah-masalah tersebut, niscaya kekayaan Alquran tersebut tampak jelas di hadapan mereka. Hal ini sekaligus menjelaskan bahwa kita adalah umat yang paling kaya dengan ajaran-ajaran yang senantiasa relevan untuk semua zaman dan tempat; dan kita tidak pantas mengikuti sistem undang-undang yang selalu berubah-ubah dan hukumhukum positif (buatan manusia), yang menyebabkan kita hidup membenci agama kita sendiri.

Pada saat ini dirasakan kebutuhan akan tafsir Mawdhuiy berdasarkan kepada beberapa pertimbangan, antara lain:

Pertama, Alquran sebagai wahyu yang diturunkan kepada Nabi yang paling sempurna adalah mengandung bermacam-macam ilmu yang bernilai tinggi, sehingga banyak tokoh ilmuwan dan para peneliti berupaya mencapai khazanah Alquran tersebut. Sementara itu, Alquran tersebut ditujukan kepada manusia sesuai dengan karakter atau fitrahnya; ajakannya bersifat universal yang bertujuan untuk membersihkan tradisitradisi, menjelaskan akidah, merobohkan tembok rasialisme, dan menegakkan undang-undang yang hak lagi adil menggantikan undang-undang tirani lagi semena-mena (Al-Farmawi, 1994: 4142).

Apabila demikian halnya, maka kita dapat menyatakan bahwa Allah akan memberikan berbagai kemudahan kepada kita. Allah tidak menuntut hal yang terlalu berat dari kita kecuali agar kita berusaha memahami dan memperhatikan serta memikirkan (kandungan) Kalam-Nya. Sebab, Allah menurunkan 
Kalam-Nya itu dimaksudkan sebagai cahaya dan petunjuk bagi umat manusia, dan mengisi Alquran tersebut dengan berbagai syariat dan hukum yang tidak mungkin dilaksanakan kecuali apabila hal tersebut betul-betul dipahami sebagai agama Ilahi dan petunjuk samawi, yang membimbing manusia menuju kebahagiaan dunia dan akhirat.

Kedua, Kajian terhadap Alquran adalah untuk mengungkapkan kepada umat manusia segala syariat dan peraturan Alquran yang berhubungan dengan kehidupan dan problema mereka, dan untuk menjelaskan kepada mereka segala hukum dan dasar-dasar yang menegaskan bahwa Alquran itu mempunyai hubungan yang erat dengan masalah politik, sosial ekonomi, peperangan, dan masalah perilaku moral; sehingga umat manusia tersebut semakin menyadari dan merasakan bahwa Alquran itu bersama mereka di dalam setiap situasi kehidupan dan mempunyai hukum yang jelas mengenai semua perilaku individu (Al-Farmawi, 1994: 4243).

Ketiga, para pelajar muslim maupun orang lain dewasa ini tidak mungkin dapat mencapai tujuan kajian yang demikian melalui kitab-kitab tafsir tahliliy, yang di dalam setiap baris uraiannya terdapat tafsir dan yang bukan tafsir. Hal yang semacam ini terjadi karena para pelajar tersebut: (1). Sudah terbiasa dengan model kajian tematik yang berusaha memahami sebuah masalah atau problem dan menghubungkan variabelvariabelnya, untuk memberikan sebuah gambaran yang utuh kepada para pembaca. (2). Oleh karena itu, metode Tahliliy tidak membantu mereka untuk sampai kepada masalah-masajah Alquran yang dimaksud, (3). Mereka itu umumnya tidak memiliki pengetahuan tentang Alquran, yang memungkinkan seseorang menghimpun berbagai aspek dan bagian masalah serta menghubungkannya satu sama lain untuk memberi- kan gambaran yang umum dan lengkap mengenai pokok masalah. (4). Mereka itu tidak mempunyai pengetahuan yang memadai tentang ilmu keislaman, yang memberanikan mereka untuk melakukan kajian mandiri. Oleh sebab itu, mayoritas mereka itu berdiri bingung di persimpangan jalan, tidak tahu jalan dan arah mana yang harus dilalui (AlFarmawi, 1994: 43).

Keempat, dewasa ini banyak orang non-Arab, baik muslim maupun nonmuslim yang dengan semboyan demi ilmu, mempelajari masalah-masalah yang dikandung oleh Alquran. Studi mereka ini tidak jarang menghasilkan tuduhan mengenai kebatilan dan kelemahan Alquran (Al-Farmawi, 1994: 43).

Tuduhan negatif ini dilontarkan oleh orang-orang yang tidak memiliki pengetahuan keislaman, atau oleh orangorang yang tidak terbiasa dengan kajian mengenai tema-tema semacam ini, yang dipelajari melalui pendekatan tematik ilmiah.

Sehubungan dengan hal di atas, para ulama dan tokoh penafsir zaman sekarang perlu memperbarui arah tafsir menuju kepada kajian Alquran secara tematik, suatu kajian yang akan mengungkapkan kepada manusia maksudmaksud dan tujuan Alquran dengan metode dan pemahaman yang relevan dengan perkembangan umat zaman sekarang. Selain itu, kajian tematik ini diharapkan mampu melenyapkan segala tuduhan negatif yang dilontarkan oleh pihak Barat dan kaum orientalis sebagai akibat dari kajian mereka yang tidak secara tematik, atau secara tematik yang terputus-putus, atau berdasar kajian tematik yang tidak betul.

Pendek kata, kebutuhan kita akan metode tafsîr mawdhû'iy pada zaman sekarang ini, di mana kita memerlukan adanya pembaruan metode dakwah islamiyah, adalah agar kita dapat mengimbangi perkembangan yang ada. Allah telah membuka wilayah yang luas di 
hadapan umat Islam dan meletakkan tugas serta tanggung jawab di atas pundak mereka untuk menguasai dunia ini. Mereka wajib menjadi pemimpin bagi bangsa-bangsa, menyeru mereka agar beriman dan taat kepada Allah, dan menunjukkan kepada mereka jalan menuju Islam, sebagaimana Rasulullah SAW dan para sahabatnya dulu berjuang dan rela mengorbankan jiwa dan raga mereka di jalan Allah. Kita tidak banyak melakukan perjuangan semacam ini untuk meninggikan kalimat Allah. Corak dan metode Tafsir Mawdhu'iy inilah yang sangat membantu kita untuk mencapai tujuan perjuangan tersebut.

\section{METODE TAFSIR TEMATIK UNTUK PENGEMBANGAN PEMI- KIRAN PENDIDIKAN ISLAM}

Pemikiran pendidikan Islam dan segala seluk-beluknya harus dirancang dan dilaksanakan berdasarkan Alquran. Menurut Sa'id Ismail Ali, sebagaimana dikutip oleh Hasan Langgulung, sumber pendidikan Islam terdiri atas enam macam, yaitu Alquran, Sunnah, kata-kata sahabat (mazhab shahâbi), kemaslahatan umat/sosial (mashâlîh al-mursalah), tradisi atau adat kebiasaan masyarakat ( 'urf), dan hasil pemikiran para ahli dalam Islam (ijtthâd) (Langgulung, 1980: 94). Keenam sumber pendidikan Islam tersebut diposisikan secara hierarkis. Artinya, rujukan pendidikan Islam diawali dari sumber pertama (Alquran) untuk kemudian dilanjutkan pada sumbersumber berikutnya secara berurutan.

Alquran dijadikan sumber pendidikan Islam yang pertama dan utama karena ia memiliki nilai absolut yang diturunkan dari Allah. Dia menciptakan manusia dan Dia pula yang mendidik manusia, di mana isi pendidikan itu telah termaktub dalam wahyu-Nya. Tidak satu pun persoalan, termasuk persoalan pendidikan yang luput dari jangkauan Alquran. Allah SWT berfirman dalam QS.
al-An'âm ayat 38: "Tiadalah Kami alpakan sesuatu pun di dalam Al-Kitab, kemudian kepada Tuhanlah mereka dihimpunkan." dan QS. al-Nahl ayat 89: "Dan Kami turunkan kepadamu Al-Kitab (Alquran) untuk menjelaskan segala sesuatu dan petunjuk serta rahmat dan kabar gembira bagi orang-orang yang berserah diri." Dua ayat di atas memberikan isyarat bahwa pendidikan Islam harus digali dari sumber autentik Islam, yaitu Alquran.

Mohamad Fadhil El-Jamaly, sebagaimana dikutip oleh Al-Syaibany mengemukakan bahwa, "Sesungguhnya mereka (kaum Muslimin) tidak membaca Alquran kecuali pada tingkat pengajaran rendah, itupun tanpa memahami maknanya dan menguasai dengan sempurna segala kandungannya. Padahal sebenarnya, Alquran itu adalah perbendaharaan maha besar meliputi perbendaharaan-perbendaharaan kebudayaan manusia, terutama segi spiritualnya. Alquran merupakan kitab pendidikan dan pengajaran secara umum, dan juga kitab pendidikan sosial, moral, dan spiritual secara khusus (Asy-Syaibaniy, 1979: 4041).

Berdasarkan kutipan-kutipan di atas dapat dipahami bahwa kajian tafsir sangat dibutuhkan dalam menggali konsep pendidikan. Metode tafsir yang paling cocok untuk tujuan dimaksud adalah metode tafsir tematik (al-tafsîr al-mawdhô'iy). Melalui metode penelitian ini, seorang peneliti dapat menemukan konsep-konsep tentang berbagai hal pendidikan. Tanpa menggunakan metode ini, seseorang tidak akan mampu menemukan pemikiran pendidikan yang bersumber pada wahyu dengan benar.

Penggunaan metode tafsir tematik dalam pengembangan pemikiran pendidikan Islam dengan alasan sebagai berikut:

Pertama, Menurut Al-Syaibany, sumber-sumber ilmu pengetahuan itu dapat dikelompokkan kepada lima sum- 
ber pokok, yaitu: indera, akal, intuisi, ilham, dan wahyu Ilahi. Islam mengakui semua sumber ini dan menghargai pentingnya sumber itu pada bidang pengetahuan yang sesuai dengannya. Sumber yang paling sesuai untuk memperoleh pengetahuan indera adalah pengamatan indera. Sumber yang paling sesuai untuk pengetahuan akal adalah akal. Sumber yang paling sesuai untuk memperoleh pengetahuan dan emosi adalah intuisi dan ilham. Sedang sumber yang paling sesuai untuk memperoleh pengetahuan agama, akhlak dan gaib secara umum adalah wahyu (Asy-Syaibaniy, 1979: 4041).

Untuk memahami pendidikan Islam tidak bisa dilakukan hanya dengan melihat sepotong apa yang ditemukan dalam realitas penyelenggaraan pendidikan Islam, tetapi mesti melihatnya dari sistem nilai yang menjadi landasan paradigmanya. Hasan Langgulung menyatakan sangat keliru jika mengkaji pendidikan Islam hanya dari lembaga-lembaga pendidikan yang muncul dalam sejarah Islam, dari kurikulum, apalagi hanya dari metode mengajar, dan melepaskan masalah idiologi Islam. Idiologi atau paradigma pendidikan Islam merupakan gambaran utuh tentang ketuhanan, alam semesta, dan tentang manusia yang dikaitkan dengan semua teori pendidikan Islam sehingga semuanya merupakan satu kesatuan yang utuh dan menyeluruh. Sehingga diperlukan suatu upaya untuk menegaskan kembali paradigma yang diperlukan untuk mengembangkan pendidikan Islam (Heryahya, 2009: 47).

Dasar paradigma pendidikan Islam identik dengan dasar Islam itu sendiri. Keduanya berasal dari sumber yang sama yaitu Alquran dan Hadis. Dari kedua sumber inilah kemudian muncul sejumlah pemikiran mengenai masalah umat Islam yang meliputi berbagai aspek, termasuk di antaranya masalah pendidikan Islam (Heryahya, 2009: 47). Sebagai dasar pendidikan Islam, Alquran dan Hadis adalah rujukan dalam mencari, membuat dan mengembangkan paradigma, konsep, prinsip, teori, dan teknik pendidikan Islam.

Kedua, Alquran adalah sumber ilmu pengetahuan yang tidak akan habishabisnya. Hal ini sesuai dengan firman Allah:

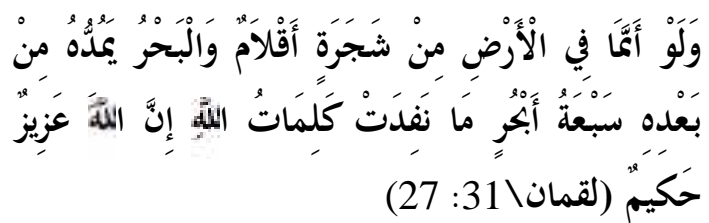

Dan seandainya pohon-pohon di bumi menjadi pena dan laut (menjadi tinta), ditambahkan kepadanya tujuh laut (lagi) sesudah (kering) nya, niscaya tidak akan habis-habisnya (dituliskan) kalimat Allah. Sesungguhnya Allah Maha Perkasa lagi Maha Bijaksana.

Dalam menafsirkan ayat di atas, Ahmad Musthafâ Al-Marâghi mengemukakan bahwa seandainya batang-batang pohon serta dahan-dahannya diruncingkan untuk dijadikan sebagai pena, kemudian air laut dijadikan tintanya, dan ditambah kepadanya tujuh laut lagi, sedangkan semua makhluk menulis dengan pena dengan tinta itu kalimat Allah yang menunjukkan kepada kebesaran dan keagunganNya, niscaya pena-pena itu akan habis semuanya dan air laut itu akan kering, sedangkan kalimat-kalimat Allah tiada habis-habisnya (Marâghiy, 1992: 176).

Rasulullah saw. bersabda dalam satu hadis (Al-Hâkim, t.th: 104):

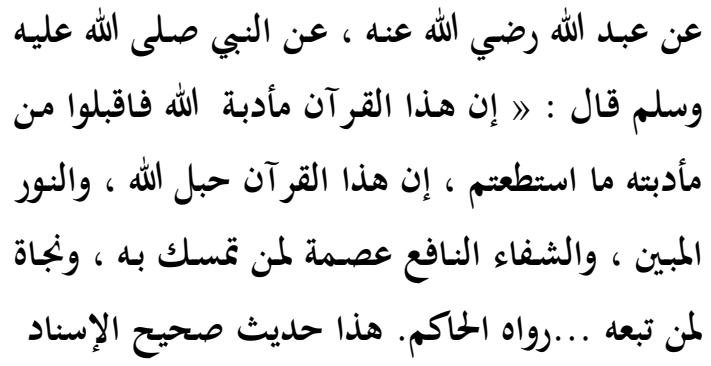

Abdullah RA meriwayatkan bahwa Nabi SAW bersabda, "Sesungguhnya 
Alquran itu merupakan hidangan dari Allah, terimalah hidangan-Nya seberapa engkau mampu. Sesungguhnya Alquran itu adalah tali Allah, cahaya terang dan penawar yang menyembuhkan serta pelindung dan penyelamat bagi orang yang mengikutinya." (HR. Al-Hakim dan Abdullah bin Masud r.a.)

Ketiga, menurut Afzalurrahman, mengkaji Alquran dan menguak kedalaman isinya adalah tugas kaum muslimin. Adalah suatu kesalahan besar apabila kaum muslim tidak memiliki kepedulian terhadap pengkajian Alquran karena sikap ini akan berarti menguburkan Alquran dan mematikan generasi Qurani pada masa yang akan datang (Afzalurrahman: 2006, v).

Berdasarkan pandangan Afzalurrahman di atas dapat dikatakan bahwa setiap ilmuwan muslim (termasuk pemikir dan peneliti pendidikan Islam) harus peduli dengan kajian-kajian yang bersumber pada Alquran dan sunnah. Bila dilihat kepada kecenderungan kebanyakan ilmuwan saat ini, memang kajian-kajian qurani dan hadisi tidak begitu menarik. Akan tetapi perlu disadari bahwa bila ilmuwan muslim tidak tertarik lagi meneliti Alquran dan hadis, maka perkembangan keilmuan Islam termasuk pendidikan Islam akan terlihat kering dari nuansa-nuansa islami. Fenomena tersebut telah banyak kelihatan dalam tulisan-tulisan tentang pendidikan Islam. Seorang penulis kadang-kadang menggunakan ayat dan hadis hanya sebatas legitimasi terhadap teori-teori atau konsep-konsep pendidikan Barat yang diagung-agungkan.

Keempat, persoalan pendidikan Islam merupakan hal yang selalu hidup dalam masyarakat muslim. Pemikiran tentangnya selalu dinamis. Dinamika pemikiran dalam pendidikan Islam harus terkendali dan harus mendapat bimbingan dari wahyu. Oleh sebab itu, pendekat- an tafsir tematik diperlukan. Petunjuk Alquran sejalan dengan perkembangan ilmu pengetahuan dan masyarakat. Pandangan ini sesuai dengan pendapat yang dikemukakan oleh M.Quraish Shihab.

Menurut M.Quraish Shihab, Ada beberapa keistimewaan metode ini antara lain, (a) menghindari problem atau kelemahan metode lain, (b) menafsirkan ayat dengan ayat atau dengan hadis Nabi, satu cara terbaik dalam menafsirkan Alquran, (C) kesimpulan yang dihasilkan mudah dipahami, dan (d) metode ini memungkinkan seseorang untuk menolak anggapan adanya ayat-ayat yang bertentangan dalam Alquran. Ia sekaligus dapat dijadikan bukti bahwa ayat-ayat Alquran sejalan dengan perkembangan ilmu pengetahuan dan masyarakat (Shihab, 2009: 180). Selain itu, melalul metode ini, sang penafslr mengundang Alquran untuk berbicara secara langsung menyangkut problem yang dihadapi atau dialami masyarakatnya. Melalui maudhû'i yakni judul yang ditetapkan, sang penafsir dapat mengajukan pertanyaan-pertanyaan yang terlintas di dalam benaknya, dan dengan demikian dapat diterapkan apa yang dianjurkan oleh Sayyidina Ali r.a: Istanthiq Al-Qur'an (Persilakanlah Alquran berbicara) (Shihab, 1998: xiii).

Dari beberapa paparan di atas dapat dipahami bahwa pendekatan tafsir tematik (al-tafsîr al-maudhû'i) dapat bahkan sangat baik digunakan dalam upaya pengembangan pemikiran pendidikan Islam. Untuk melaksanakannya, penafsir tematik perlu membekali diri dengan wawasan seputar metode tafsir tematik seperti persyaratan dan langkahlangkah pelaksanaannya. Untuk mendapatkan hasil yang optimal, penafsir bukan saja harus menguasai metodologi melainkan juga harus mengikhlaskan niat karena Allah karena Alquran adalah kitab suci yang bermukjizat. Dengan sikap yang angkuh dan takabur, hidayah 
Alquran akan sulit diperoleh kendatipun seorang itu berusaha menggapainya.

\section{PENUTUP}

Pemikiran pendidikan Islam harus dikembangkan dengan berbagai metode termasuk metode tafsir tematik. Tanpa mengabaikan metode-metode lain, metode tafsir tematik sangat dibutuhkan dalam menggali dan merumuskan konsep pendidikan Islam. Dengan menggunakan

\section{DAFTAR RUJUKAN}

Afzalurrahman, 2006. Indeks Alquran, Terjemahan Ahsin W. Al-Hafidz, Jakarta: Bumi Aksara, cet. ke-3

Al-Farmawi, Abd al-Hayy, 1994. Metode Tafsîr Mawdhû'iy: Sebuah Pengantar,Terjemahan Suryan A. Jamrah, Judul Asli, "Al-Bidâyah Fi al-Tafsîr al-Mawdhû'iy: Dirâsah Manhajiyah Mawdhû'iyah", Jakarta: PT RajaGrafindo Persada, Cet. ke-1

Hâkim, Al-Mustadrak 'alâ al-Shahîhayn, juz 5, h. 104 dalam Al-Maktabah al-Syâmilah

Idris, Jamaluddin, Kompilasi Pemikiran Pendidikan, Banda Aceh: Taufiqiyahh Sa'adah, , cet. Ke-1

Jalaluddin dan Usman Said, 1994. Filsafat Pendidikan Islam Konsep dan Perkembangan Pemikirannya, Jakarta: RajaGrafindo, cet. ke-1

Langgulung, Hasan, 1980. Beberapa Pemikiran tentang Pendidikan Islam, Bandung: al-Ma' arif metode ini, peneliti akan menemukan berbagai konsep pendidikan yang meliputi berbagai faktor pendidikan Islam berdasarkan petunjuk wahyu. Sesuai dengan prosedur penelitian tafsir tematik, hadis-hadis yang relevan dan hasil ijtihad pakar pendidikan juga diikutsertakan dalam membahas dan menjelaskan konsep pendidikan dalam Alquran. Dengan demikian, lahirlah konsep yang utuh tentang suatu masalah pendidikan Islam.

Marâghiy, Ahmad Muşthafa, 1992. Tafsîr al-Marâghiy, juz 21, Terjemahan K. Anshori Umar Sitanggal dkk., (Semarang: Toha Putra, cet. ke-2

Nizar, Samsul, 2001. Pengantar Dasardasar Pemikiran Pendidikan Islam, Jakarta: Gaya Media Pratama

Shihab,M.Quraish, 2009. Membumikan Al-Quran, Fungsi dan Peran Wahyu dalam Kehidupan Masyarakat, Bandung: Mizan, , cet. ke-3, ,1998. Wawasan Al-Quran Tafsir Maudhu'i atas Pelbagai Perseolan Umat, Bandung: Mizan, Cet ke7

As-Syaibany, Omar Mohamad AlToumy, 1979. Falsafah Pendidikan Islam, Terjemahan Hasan Langgulung, Jakarta: Bulan Bintang, Cet. ke-1

Umar, Bukhari, 2009. Pemikiran Pendidikan Islam, Batusangkar, STAIN Batusangkar Press. 